\title{
Pengaruh Ibu Bersalin dengan Preeklamsia terhadap Kejadian Resiko Tinggi pada Bayi Baru Lahir di RSD Dr. Soebandi Jember Tahun 2017
}

\author{
Eni Subiastutik ${ }^{1}$, Syiska Atik $\mathbf{M}^{\mathbf{1}}$, Shofiyatul Hafiyah ${ }^{1}$ \\ Poltekkes Kemenkes Malang, Indonesia ${ }^{1}$ \\ e-mail : enisubiastutik@gmail.com
}

\begin{abstract}
Preeklamsia is cause namber two maternal death in Indonesia which one will cause accident high risk on baby is asphyxia, low birth weight, intrauterin growth retriction (IUGR), and intrauterine fetal death (IUFD) because there is spasmus arterioles so decrease blood how to placenta that result oksigenation decrease and nutrition. Research purposes to know maternal influence with preeclamsia to high ris accident on new bron baby in RSD $d r$ Soebandi in 2017. Research desain of analytic dynamic correlation with approach cross sectional, the number of samples of 105 respondents using secondary data medical records RSD dr. Soebandi Jember in January - December 2017 and analyzed with chi-square, KK. And correlation lambda. Analysis result on asphyxia with value sig 2 sided $=0,003<\alpha(0,05)$ and $K K 0,280$ on low birth weight there is sig 2 sided $=$ $0,022<\alpha(0,05)$ and $K K 0,218$, while IUGR there is $\lambda$ count value of $0,000<3,841$ and IUFD there is $\lambda$ count value of 0,000 <3,841. Conclution there is low or weak connection but for sure between maternal preeclamsia with asphyxia and low birth weight. But to IUGR and IUFD there not conection with maternal preeclamsia. Expected to the midwife to do the perform equality pregnancy service.
\end{abstract}

Keywords: asphyxia, BBLR, IUGR, IUFD, preeclamsia

\section{Pendahuluan}

Preeklampsia merupakan kondisi spesifik pada kehamilan yang ditandai dengan adanya disfungsi plasenta dan respon maternal terhadap adanya inflamasi sistemik dengan aktivasi endotel dan koagulasi. Diagnosis preeklampsia ditegakkan berdasarkan adanya hipertensi spesifik yang disebabkan kehamilan disertai dengan gangguan sistem organ lainnya pada usia kehamilan diatas 20 minggu. Preeklampsia, sebelumya selalu didefinisikan dengan adanya hipertensi dan proteinurin yang baru terjadi pada kehamilan (new onset hypertension with proteinuria) (Dachlan, Erry, 2016). Penyebab terjadinya preeklamsi saat ini tidak bisa diketahui dengan pasti, adapun teoriteori tersebut antara lain peran prostasiklin dan tromboksa, faktor imunologis, faktor genetik, faktor iskemia plasenta.

Keberhasilan upaya kesehatan ibu, di antaranya dapat dilihat dari indikator angka Kematian Ibu (AKI). AKI adalah jumlah kematian ibu selama masa kehamilan, persalinan dan nifas yang disebabkan oleh kehamilan, persalinan, dan nifas di setiap 100.000 kelahiran hidup (Profil Kesehatan Indonesia, 2015). Menurut World Healt Organization (WHO) setiap harinya sebanyak 830 ribu ibu meninggal akibat komplikasi pada masa kehamilan, persalinan dan nifas. AKI sepanjang tahun 2015 mencapai 303.000 (WHO, 2015). Sedangkan angka kematian bayi di Indonesia sebesar 31/1.000 kelahiran hidup, dimana penyebab antara lain adalah infeksi neonatorum, BBLR dan asfiksia dengan persentase sebesar 23\% (Profil Kesehatan Indonesia, 2015).

Penyebab kematian ibu disebabkan oleh beberapa faktor yaitu diantaranya preeklamsia. Menurut World Healt Organization (WHO) 2016, angka kejadian preeklamsia di seluruh dunia sebanyak 861 dari 96.494 ibu hamil. Di indonesia angka kejadian preeklamsia sekitar $7-10 \%$ dari seluruh kehamilan. Sedangkan di Jawa Timur menunjukkan bahwa penyebab tertinggi kematian ibu pada tahun2015 adalah Eklampsia yaitu sebesar $31 \%$ atau sebanyak 162 orang (Profil Kesehatan Provinsi Jawa Timur 2015). Angka kejadian preeklamsia di Kabupaten Jember sebesar 28,8\%, sedangkan angka kematian di Kabupaten Jember pada tahun 2016 sebesar 33 orang yang salah satunya disebabkan karena preeklamsia (Dinas Kesehatan Kabupaten Jember 2016). Menurut hasil penelitian angka kejadian preeklamsia di RSD dr Soebandi Jember tercatat ada 105 ibu bersalin dengan preeklamsia dari bulan Januari sampai dengan bulan September 2017.

Sustainable Development Goals (SDGs) 2015-2030 berkomitmen untuk menurunkan Angka Kematian Ibu (AKI) danAngka Kematian Bayi (AKB). SDGs mempunyai 17 tujuan dan 169 target,tujuan pertama, kedua dan ketiga berhubungan dengan kesehatan. Sedangkan tujuan yang berhubungan dengan penurunan AKI adalah 
tujuan yang ketiga yaitu dengan target penurunan AKI sebesar 70 per 100.000 kelahiran hidup $(\mathrm{KH})$.

Preeklamsia dapat menyebabkan komplikasi pada ibu dan janin. Komplikasi yang terberat adalah kematian ibu dan janin. Dampak preeklamsi terhadap ibu yaitu solusio plasenta, hipofibrinogenemia, hemolisis, perdarahan otak, kelainan mata, edema paruparu, nekrosis hati, sindroma HELLP, kelainan ginjal. Sedangkan pada janin yaitu prematuritas, asfiksia, dan kematian janin intra uterin. Dua kunci utama yang berperan dalam patogenesis preeklampsia adalah invasi sitotrotrofoblas endovaskuler pada arteri spiralis dan disfungsi sel endothel (Prawiroharjo, 2010). Salah satu penyebab yang mampu mengakibatkan kerusakan endothel adalah stres oksidatif. Stres oksidatif terjadi apabila konsentrasi radikal bebas di dalam tubuh melebihi kapasitas antioksidan atau berkurangnya kadar antioksidan di dalam tubuh (Saifuddin, 2010)

Terjadinya preeklampsia dapat dideteksi secara dini dengan memakai Mean Arterial Pressor test (MAP) dan Rool Over Test (ROT). Pemeriksaan antenatal yang teratur dan bermutu serta teliti, mengenali tanda-tanda sedini mungkin (terdapat kenaikan tekanan darah, protein urine serta odema), lalu diberikan pengobatan yang cukup supaya penyakit tidak menjadi lebih berat, harus selalu waspada terhadap kemungkinan terjadinya preeklampsia kalau ada faktor-faktor predeposisi, diet tinggi protein, dan rendah lemak, karbohidrat, garam dan penambahan berat badan yang tidak berlebihan perlu dianjurkan, Mencari pada tiap pemeriksaan tanda-tanda preeklampsia

Mengingat preeklamsia dapat berdampak buruk terhadap kondisi bayi yang dilahirkan maka perlu dilakukan penelitian tentang kondisi bayi yang dilahirkan oleh ibu dengan preeklamsia. Berdasarkan penjelasan di atas, peniti tertarik untuk mengetahui pengaruh ibu bersalin dengan preeklamsia terhadap kejadian resiko tinggi pada bayi baru lahir di RSD dr. Soebandi tahun 2017.

\section{Metode}

Penelitian ini merupakan jenis observasional analitik dengan menggunakan pendekatan cross sectional, yaitu variabel bebas dan variabel terikat dikumpulkan dalam waktu bersamaan (Nursalam, 2009) yaitu dalam penelitian ini mengidentifikasi pengaruh ibu bersalin dengan preeklamsia terhadap kejadian resiko tinggi pada bayi baru lahir di RSD dr Soebandi Jember Tahun 2017. Penelitian ini menggunakan pendekatan crossectional, yaitu variabel bebas dan variabel terikat dikumpulkan dalam waktu bersamaan (Nursalam, 2009). Penelitian ini dilakukan pada bulan Maret - April 2018 di RSD dr. Soebandi Jember .

\subsection{Metode Pengumpulan Data}

Populasi pada penelitian ini adalah semua ibu bersalin dengan preeklamsi di RSD dr. Soebandi Jember pada bulan Januari sampai dengan Desember Tahun 2017 sejumlah 170 ibu bersalin dengan preeklamsi, diperkirakan berdasarkan rata - rata dari study pendahuluan bulan Januari sampai dengan Desember tahun 2017.

Teknik pengambilan sampel disini dilakukan dengan cara Non Probobality Sampling (pengambilan bukan secara acak atau non random adalah pengambilan sampel yang tidak didasarkan atas kemungkinan yang dapat diperhitungkan, tetapi semata-mata). Pengambilan sampel pada penelitian ini dengan tehnik Purposive Sampling yaitu pengambilan sampel didasarkan pada suatu pertimbangan tertentu yang dibuat oleh peneliti sendiri, berdasarkan ciri atau sifat-sifat populasi yang sudah diketahui sebelumnya (Notoatmodjo, 2010). Instrumen yang digunakan dalam penelitian ini pada variabel independen maupun variabel dependen sama-sama menggunakan rekam medik pasien.

\subsection{Metode Analisis Data}

Hasil pengumpulan data dilakukan pengolahan untuk mengetahui adakah pengaruh ibu bersalin dengan preeklamsia terhadap kejadian resiko tinggi pada bayi baru lahir di RSD dr. Soebandi tahun 2017. Hasil penelitian variabel independen akan ditabulasi silangkan dengan variabel dependen dalam bentuk tabel silang. Kemudian dianalisis menggunakan uji Chi-Square (Chi Kuadrat) dan korelasi lambda dua sampel.

\section{Hasil dan Pembahasan}

Dalam penelitian ini pelaksanaan dan pengumpulan data dilaksanakan pada bulan Maret-April 2018 diruang rekam medis RSD dr. Soebandi Jember. 
ISSN 2354-5852

E-ISSN 2579-5783

Data khusus identifikasi kejadian ibu bersalin aterm pervaginam belakang kepala dengan preeklamsia dapat dilihat pada tabel 1 .

Tabel 1. Distribusi frekuensi jenis preeklamsia ibu bersalin aterm pervaginam di RSUD dr. Soebandi Jember Januari - Desember 2017.

\begin{tabular}{lcc}
\hline Preeklamsia & Frekuensi (Orang) & Persentase (\%) \\
\hline PE & 39 & 37,14 \\
PEB & 66 & 62,86 \\
\hline Jumlah & 105 & 100 \\
\hline
\end{tabular}

Sumber: Rekam Medis Pasien

Berdasarkan table 1 menunjukkan bahwa ibu yang mengalami preeklamsia (PE) sebesar 37,14\% dan yang mengalami preeklamsia berat (PEB) dengan persentase sebesar $62,86 \%$.

Identifikasi kejadian asfiksia bayi baru lahir dari ibu preeklamsia dapat dilihat pada table 2 .

Tabel 2. Distribusi frekuensi asfiksia bayi baru lahir dari ibu preeklamsia di RSUD dr. Soebandi Jember Januari -Desember 2017.

\begin{tabular}{lcl}
\hline $\begin{array}{l}\text { Kejadian } \\
\text { Asfiksia }\end{array}$ & Frekuensi (Orang) & $\begin{array}{l}\text { Persentase } \\
(\%)\end{array}$ \\
\hline Tidak Asfiksia & 64 & 62,75 \\
Asfiksia & 38 & 37,25 \\
\hline \multicolumn{1}{c}{ Jumlah } & 102 & 100 \\
\hline
\end{tabular}

Sumber: RSD Soebandi, 2017

Berdasarkan tabel 2 menunjukkan bahwa kejadian asfiksia bayi baru lahir dari ibu preeklamsia sebagai berikut, bayi lahir dengan tidak asfiksia sebesar $62,75 \%$, sedangkan bayi lahir dengan asfiksia sebesar 37,25\%. Identifikasi kejadian BBLR dari ibu preeklamsia dapat dilihat pada tabel 3.

Tabel 3. Distribusi frekuensi BBLR dari ibu preeklamsia di RSUD dr. Soebandi Jember Januari Desember 2017.

\begin{tabular}{lcl}
\hline $\begin{array}{l}\text { Kejadian } \\
\text { BBLR }\end{array}$ & Frekuensi (Orang) & $\begin{array}{l}\text { Persentase } \\
(\%)\end{array}$ \\
\hline BBLN & 66 & 62,86 \\
BBLR & 39 & 37,14 \\
\hline Jumlah & 105 & 100 \\
\hline
\end{tabular}

Sumber: RSD Soebandi, 2017

Berdasarkan tabel 3 menunjukkan bahwa kejadian BBLR dari ibu preeklamsia sebagai berikut bayi lahir dengan berat badan normal sebesar $62,86 \%$, dan bayi lahir dengan BBLR sebesar 37,14\%.

Identifikasi kejadian IUGR dari ibu preeklamsia dapat dilihat pada table 4 .

Tabel 4. Distribusi frekuensi IUGR dari ibu preeklamsia di RSUD dr.Soebandi Jember Januari Desember 2017

\begin{tabular}{lcc}
\hline $\begin{array}{l}\text { Kejadian } \\
\text { IUGR }\end{array}$ & $\begin{array}{l}\text { Frekuensi } \\
\text { (Orang) }\end{array}$ & Persentase (\%) \\
\hline Tidak IUGR & 102 & 97,14 \\
IUGR & 3 & 2,86 \\
\hline Jumlah & 105 & 100 \\
\hline
\end{tabular}

Sumber: RSD Soebandi, 2017

Berdasarkan tabel diatas menunjukkan bahwa kejadian IUGR dari ibu preeklamsia sebagai berikut, bayi lahir tidak dengan IUGR sebesar 97,14\%, dan bayi lahir dengan IUGR sebesar 2,86\%. Identifikasi kejadian IUFD dari ibu preeklamsia dapat dilihata pada tabel 5.

Tabel 5. Distribusi frekuensi IUFD dari ibu preeklamsia di RSUD dr. Soebandi Jember Januari Desember 2017.

\begin{tabular}{ccc}
\hline Kejadian IUFD & Frekuensi (Orang) & Persentase (\%) \\
\hline Tidak IUFD & 101 & 96,19 \\
IUFD & 4 & 3,81 \\
\hline Jumlah & 105 & 100 \\
\hline
\end{tabular}

Sumber: RSD Soebandi, 2017

Berdasarkan tabel 5 menunjukkan bahwa kejadian IUFD dari ibu preeklamsia sebagai berikut bayi lahir tidak IUFD sebesar $96,19 \%$, dan bayi lahir dengan IUFD sebesar $3,81 \%$.

Analisa data pengaruh ibu bersalin preeklamsia terhadap kejadian resiko tinggi bayibaru lahir di RSD dr Soebandi Jember tahun 2017 dapat dilihat pada tabel 6

Tabel 6. Distribusi frekuensi analisa data pengaruh ibu bersalin preeklamsia terhadap kejadian resiko tinggi bayibaru lahir di RSD dr Soebandi Jember Januari-Desember 2017.

\begin{tabular}{lcccc}
\hline & PE & PEB & $\begin{array}{c}\rho- \\
\text { value }\end{array}$ & Sig-2 \\
\hline Tidak Asfiksia & 32 & 35 & 8,941 & 0,003 \\
Asfiksia & 7 & 31 & & \\
\hline BBLN & 32 & 49 & 5,231 & 0,022 \\
BBLR & 7 & 17 & & \\
\hline Tidak IUGR & 39 & 63 & 0,000 & 0,000 \\
IUGR & 0 & 3 & & \\
\hline Tidak IUFD & 39 & 62 & 0,000 & 0,000 \\
IUFD & 0 & 4 & & \\
\hline
\end{tabular}

Sumber: RSD Soebandi, 2017

Berdasarkan tabel 6 menunjukkan bahwa pada preeklamsia sebagian besar bayi yang dilahirkan tidak mengalami asfiksia sebanyak 32 bayi, BBLN sebanyak 32 bayi, tidak IUGR sebanyak 39 bayi, dan tidak IUFD sebanyak 39 bayi. Sedangkan pada ibu yang mengalami preeklamsia berat bayi yang dilahirkan sebagian ada yang mengalami asfiksia sebanyak 35 bayi, BBLR sebanyak 17 
bayi, IUGR sebanyak 3 bayi dan IUFD sebanyak 4 bayi.

Uji statistik chi-square dengan taraf signifikasi 5\% $(0,05)$ digunakan untuk menguji pengaruh ibu bersalin dengan preeklamsia terhadap kejadian resiko tinggi pada bayi baru lahir di RSD dr Soebandi tahun 2017. Hasil uji hipotesis pada kejadian asfiksia dengan uji chi square didapatkan nilai $\chi^{2}$ hitung sebesar $8,941>3,841\left(\chi^{2}\right.$ tabel dengan $\left.\mathrm{dk} 1\right)$ dan sig 2 sided $=0,003<\alpha(0,05)$ artinya Ho ditolak atau ada hubungan. Sedangkan nilai koefisiensi kontingensi (KK) sebesar 0,280 yang berarti bahwa terdapat hubungan yang rendah atau lemah tapi pastiantara ibu bersalin preeklamsia dengan asfiksia bayi baru lahir.Pada hasil uji hipotesis kejadian BBLR dengan uji chi square didapatkan nilai $\chi^{2}$ hitung sebesar5,231>3,841 $\left(\chi^{2}\right.$ tabel dengan $\left.\mathrm{dk} 1\right)$ dan sig 2 sided $=0,022>$ $\alpha(0,05)$ artinya Ho ditolak atauada hubungan. Sedangkan nilai koefisiensi kontingensi (KK) sebesar 0,218 yang berarti bahwa terdapat hubungan yang rendah atau lemah tapi pasti antara ibu bersalin preeklamsia dengan kejadian BBLR. Sedangkan hasil uji hipotesis pada kejadian IUGR dengan korelasi lamda didapatkan nilai $\lambda$ hitung sebesar $0,000<3,841$ (dengan $\mathrm{dk} 1$ ) artinya Ho diterima atau tidak ada hubungan antara ibu bersalin preeklamsia dengan kejadian IUGR pada bayi baru lahir. Dan pada hasil uji hipotesis kejadian IUFD dengan uji korelasi lamda didapatkan nilai $\lambda$ hitung sebesar $0,000<3,841\left(\chi^{2}\right.$ tabel dengan dk 1) artinya Ho diterima atau tidak ada hubunganantara ibu bersalin preeklamsia dengan kejadian IUFD bayi baru lahir.

Hasil uji hipotesis pada kejadian asfiksia dengan uji chi square didapatkan nilai $\chi^{2}$ hitung sebesar 8,941>3,841 $\quad\left(\chi^{2}\right.$ tabel dengan dk 1) dan sig 2 sided $=0,003<\alpha$ $(0,05)$ artinya Ho ditolak atau ada hubungan. Sedangkan nilai koefisiensi kontingensi (KK) sebesar 0,280yang berarti bahwa terdapat hubungan yang rendah atau lemah tapi pasti antara ibu bersalin preeklamsia dengan asfiksia bayi baru lahir. Pada hasil uji hipotesis kejadian BBLR dengan uji chi square didapatkan nilai $\chi^{2}$ hitung sebesar 5,231> 3,841 ( $\chi^{2}$ tabel dengan dk 1) dan sig 2 sided $=0,022>\alpha$ $(0,05)$ artinya Ho ditolak atau ada hubungan. Sedangkan nilaikoefisiensi kontingensi (KK) sebesar 0,218 yang berarti bahwa terdapat hubungan yang rendah atau lemah tapi pasti antara ibu bersalin preeklamsia dengan kejadian BBLR. Sedangkan hasil uji hipotesis pada kejadian IUGR dengan korelasi lamda didapatkan nilai $\lambda$ hitung sebesar $0,000<3,841$ (dengan dk 1) artinya Ho diterima atau tidak ada hubungan antara ibu bersalin preeklamsia dengan kejadian IUGR pada bayi baru lahir. Dan pada hasil uji hipotesis kejadian IUFD dengan uji korelasi lamda didapatkan nilai $\lambda$ hitung sebesar $0,000<3,841$ (dengan $\mathrm{dk} 1$ ) artinya Ho diterima atau tidak ada hubungan antara ibu bersalin preeklamsia dengan kejadian IUFD bayi baru lahir.

Asfiksia bayi baru lahir merupakan salah satu dari risiko yang disebabkan oleh preeklamsia. Pada tabel 4.12 menunjukkan bahwa hasil yang diperoleh dari penelitian ibu bersalin spontan yang menderita preeklamsia di RSD dr. Soebandi Jember tahun 2017 didapatkan bahwa ibu pada preeklamsia paling banyak melahirkan bayi tidak asfiksia. Sedangkan pada preeklamsia berat banyak ibu melahirkan bayi dengan asfiksia. Hal ini sesuai dengan teori bahwa asfiksia pada bayi baru lahir terjadi karena pada ibu preeklamsia terjadi gangguan peredaran darah yang dapat mengakibatkan spasme arteriol mendadak yang berakibat terjadinya pengecilan aliran darah menuju retroplasenter yang dapat menyebabkan gangguan pertukaran oksigen dan karbon dioksida sehingga terjadi asfiksia (Manuaba, 2008).

Kejadian berat badan lahir rendag (BBLR) pada bayi baru lahir juga merupakan salah satu dari risiko yang disebabkan oleh preeklamsia. Pada table 4.12 menunjukkan bahwa hasil yang diperoleh dari penelitian ibu bersalin spontan yang menderita preeklamsia di RSD dr. Soebandi Jember tahun 2017 didapatkan bahwa ibu pada preeklamsia paling banyak melahirkan bayi dalam berat badan lahir normal. Sedangkan pada preeklamsia berat banyak ibu melahirkan bayi dengan berat badan lahir rendah. Kejadian tersebut sesuai dengan teori Saifuddin (2010) bahwa berat badan lahir rendah salah satu faktor penyebabnya adanya kelainan pada fungsi plasentanya yang mana dikarenakan terjadi spasmus arteriola spiralis desidua yang mengakibatkan menurunnya aliran darah ke plasenta sehingga terjadi gangguan transpor nutrisi dari ibu ke janin sehingga terdapat gangguan dalam persediaan nutrisi.

Sedangkan untuk kejadian IUGR dan 
IUFD merupakan salah satu dari risiko yang disebabkan oleh preeklamsia. Pada tabel 4.12 menunjukkan bahwa hasil yang diperoleh dari penelitian ibu bersalin yang menderita preeklamsia di RSD dr. Soebandi Jember tahun 2017 didapatkan bahwa ibu pada preeklamsia tidak ada yang melahirkan bayi dengan IUGR dan IUFD. Sedangkan pada preeklamsia berat terdapat ibu melahirkan bayi dengan IUGR sebanyak 3 orang dan IUFD sebanyak 4 orang. Hal tersebut sesuai dengan teori Saifuddin (2010) bahwa bayi yang dilahirkan karena ibu yang menderita preeklamsia saat kehamilan terjadi spasmus arteriola spiralis desidua yang mengakibatkan menurunnya aliran darah ke plasenta sehingga terjadi gangguan fungsi plasenta yang mengakibatkan terjadi hipoksia janin dan apabila kehamilan berlangsung lama sampai dengan aterm resiko intrauterin growth retriction (IUGR) dan intrauterin fetal deat (IUFD) semakin besar. Akan tetapi juga terdapat beberapa faktor penyebab IUGR dan IUFD lainnya selain preeklamsia antara lain faktor maternal (penyakit jantung sianosis, diabetes melitus lanjut, hemoglobinopati, penyakit autoimun, malnutrisi, merokok, narkotika, kelainan uterus, trombofilia), faktor plasenta dan tali pusat (kelainan plasenta, solusio plasenta kronik, plasenta previa, kelainan insersi tali pusat, kelainan tali pusat) dan faktor janin sendiri (kelainan kromoso atau genetik dan infeksi pada janin) (Noroyono Wibowo, 2016).

Berdasarkan hasil penelitian sebelumnya yang dilakukan oleh Raras (2011) menyebutkan bahwa preeklamsia berat dapat menghasilkan keluaran perinatal meliputi asfiksia neonatorum $(16,7 \%)$, berat bayi lahir rendah $(37 \%)$, pertumbuhan janin terhambat $(6,9 \%)$, kelahiran preterm $(28,3 \%)$, dan kematian perinatal (93\%).

\section{Simpulan dan Saran \\ 4.1 Simpulan}

Kesimpulan penelitian ini sebagai adalah ibu bersalin dengan preeklamsia katagori terbanyak adalah preeklamsia berat (PEB) sebesar 62,86\%, bayi baru lahir dari ibu preeklamsia yang mengalami asfiksia sebesar $37,25 \%$, bayi baru lahir dari ibu preeklamsia yang mengalami BBLR sebesar 37,14\%, bayi baru lahir dari ibu preeklamsia yang mengalami IUGR sebesar $2,86 \%$, bayi baru lahir dari ibu preeklamsia yang mengalami IUFD sebesar 3,81\%, terdapat hubungan dengan korelasi yang rendah atau lemah tapi pasti yaitu ibu bersalin dengan preeklamsia dapat melahirkan bayi dengan berat badan lahir rendah (BBLR) dan asfiksia.

\subsection{Saran}

Sebagai bahan kajian kepustakaan untuk penelitian selanjutnya khususnya penelitian mengenai preeklamsia dengan kejadian resiko tinggi pada bayi baru lahir dengan jumlah sampel yang lebih besar. Dari hasil penelitian didapatkan paling banyak faktor predisposisi risiko preeklamsia dengan usia $<20$ tahun atau $>35$ tahun sehingga dapat direkomendasikan untuk peneliti selanjunya untuk melakukan penelitian dengan judul "Pengaruh usia ibu terhadap Kejadian Preeklamsia".

\section{Daftar Pustaka}

Arikunto, S., (2013). Manajemen Penelitian, Jakarta: PT. Rineka Cipta.

Arikunto, S., (2010). Prosedur Penelitian Suatu Pendekatan Praktek, Jakarta: PT. Rineka Cipta.

Dachlan, Erry, et al., (2016). Preeklamsia Eklamsia dan Perdarahan Pasca Persalinan., Satuan Tugas Penurunan Angka Kematian Ibu Jawa Timur.

Dewi, V., (2010). Asuhan Neonatus Bayi dan Anak Balita, Jakarta: Medika Salemba.

Dinas Kesehatan Kabuten Jember. (2016). Profil Kesehatan Kabupaten Jember.

Dinas Kesehatan Profinsi Jawa Timur. (2015). Profil Kesehatan Jawa Timur. http://dinkes.jatimprov.go.id

JNPK-KR (2008). Asuhan Persalinan Normal, Jakarta: Jaringan Nasional Pelatihan Klinik 2011.

Kemenkes RI. (2016). Profil Kesehatan Indonesia. Kesehatan. https://doi.org/10.111/evo.12990 